\title{
Third Party Beneficiary Contracts in England
}

\begin{abstract}
" $[I] f$ there is one thing which more than another public policy requires it is that men of full age and competent understanding shall have the utmost liberty of contracting, and their contracts when entered into freely and voluntarily shall be held sacred and shall be enforced by the Courts of justice." Sir George Jessel, Master of the Rolls. ${ }^{1}$
\end{abstract}

If $A$ wishes to confer a benefit, say Blackacre, upon $C$, he may attempt to accomplish this by the following transaction: $A$ pays $\$ 5,000$ to $B$, in return for which $B$ promises to convey Blackacre to $C$. This is an example of a third party beneficiary contract, in which $B$ is the promisor, $A$ the promisee, and $C$ the beneficiary. If $A$ uses this means to extinguish an obligation owed by him to $C, C$ is a "creditor beneficiary"; if $A$ is simply making a gift of Blackacre to $C, C$ is a "donee beneficiary."2

This arrangement would operate successfully in the United States, ${ }^{3}$ in most other common law countries, ${ }^{4}$ and in civil law jurisdictions; $C$ would gain thereby the right to enforce the contract for his own benefit. In England and Australia, however, the prevailing rule, usually attributed to the 1861 case of Tweddle $v$. Atkinson, ${ }^{5}$ denies that such a

1 Printing \& Numerical Registering Co. v. Sampson, L.R. 19 Eq. 462, 465 (1875).

2 Restatement of Contracts $\S 133(1)$ (1932). A third category, "incidental beneficiary," describes one who might benefit by performance of the contract, but only as an incidental consequence to which the parties are ambivalent. The broker is an incidental beneficiary of a real estate contract unless his rights are specified therein. Since such a beneficiary is usually not named or described in the agreement, and the benefit to him is not a principal motivation for $A$ 's giving consideration to $B$, his interest is disregarded in favor of the ancillary rights discussed in text following note 16 infra. For examples of incidental beneficiaries under English law, see Scruttons, Ltd. v. Midland Silicones, Ltd., [1962] A.C. 446, [1962] 2 W.L.R. 186 (1961); Vandepitte v. Preferred Accident Ins. Corp., [1933] A.C. 70 (P.C. 1932) (Can.).

This comment will be concerned with agreements made for the express benefit of the beneficiary, although $A$ himself may also have a substantial interest in performance.

3 Lawrence v. Fox, 20 N.Y. 268 (1859), is the leading case.

4 Canada (e.g., Selby v. Selby, [1956] 3 D.L.R.2d 275 (N.B.)); Scotland (the jus quaesitum tertio); Ireland; and South Africa.

5 Reported with considerable variation in 1 B. \& S. 393, 121 Eng. Rep. 762, in 30 L.J.Q.B. 265, and in 4 L.T. 468, [1861-73] All E.R. Rep. 369 (Q.B. 1861). The "rule of Tweddle $v$. Atkinson," discussed in note 8 infra, was accepted without citation by the House of Lords in Dunlop Pneumatic Tyre Co., v. Selfridge \& Co., [1915] A.C. 847, [1914-15] All E.R. Rep. 333 (1915); the classic statement of the rule is that of Viscount Haldane, Lord Chancellor, in that case: 
contract can create any right of enforcement in the beneficiary. In other words, $C$ cannot sue for relief in his own right in the event of $B$ 's breach; moreover, while $A$-or his personal representative after $A$ 's death-is entitled to enforce the contract, $C$ cannot compel him to do so, nor may he coerce $A$ 's choice among the available remedies.

A recent case in the House of Lords illustrates the situation. Beswick v. Beswick ${ }^{6}$ involved a contract made by Peter Beswick $(A)$, an aging merchant, with his nephew $(B)$, by which $A$ turned his business over to $B$ in return for $B$ 's promise to pay an annuity to Mrs. Beswick $(C)$ to commence on $A$ 's death. After $A$ died, $B$ made one payment and then refused to continue, whereupon the widow sued. Following the Tweddle rationale, Mrs. Beswick was held to have no cause of action in her own right ${ }^{7}$ but in her second capacity as $A^{\prime}$ 's administratrix she was granted a decree of specific performance. Thus through the for-

My Lords, in the law of England certain principles are fundamental. One is that only a person who is a party to a contract can sue on it. Our law knows nothing of a jus quaesitum tertio arising by way of contract. Such a right may be conferred by way of property, as, for example, under a trust, but it cannot be conferred on a stranger to a contract as a right to enforce the contract in personam.

Id. at 853. The Tweddle rule was explicitly followed in Scruttons, Ltd. v. Midland Silicones, Ltd., [1962] A.C. 446, [1962] 2 W.L.R. 186, [1962] I All E.R. I (1961).

The lower courts have also conformed to the doctrine of Tweddle v. Atkinson and an earlier case, Colyear v. Countess of Mulgrave, 2 Keen 81, 48 Eng. Rep. 559 (Ch. 1836). E.g., In re Miller's Agreement, [1947] Ch. 615; In re Schebsman, [1944] Ch. 83 (C.A. 1943), dismissing appeal from [1943] Ch. 366; Cleaver v. Mutual Reserve Fund Life Ass'n, [1892] 1 Q.B. 147 (C.A. 1891); In re Empress Eng'r Co., 16 Ch. D. 125 (C.A. 1880); In re D'Angibou, I5 Ch. D. 228 (C.A. 1880). See also In re Pryce, [1917] I Ch. 234 (1916).

6 [1968] A.C. 58, [1967] 3 W.L.R. 932, [1967] 2 All E.R. I197 (1967), aff'g in part [1966] Ch. 538, [1966] 3 W.L.R. 396, [1966] 3 All E.R. I (C.A.), which rev'd [1965] 3 All E.R. 858 (Ch. Ct. of the County Palatine of Lancaster).

$\tau$ The principle of Tweddle $v$. Atkinson was only implicitly approved in Beswick, since the House of Lords proceeded on the basis that on appeal it was not contested that the common law denied the beneficiary a right of action. However, the court clearly demonstrated its agreement with such a concession. Lord Reid, speaking of In re Miller's Agreement, [1947] $\mathrm{Ch}$. 615, declared that decision to be "clearly right": "The daughters, not being parties to the agreement, had no right to sue for their annuities." [1968] A.C. at 75, [1967] 3 W.L.R. at 938. Lord Hodson mentions in passing "the common law rule that a contract such as this one, which purports to confer a benefit on a stranger to the contract, cannot be enforced by the stranger." Id. at 78, [1967] 3 W.L.R. at 941. Lord Pearce referred to the common law rule as a "mechanical defect" (see infra note 30). Id. at 89, [1967] 3 W.L.R. at 950. And Lord Upjohn's remarks to the effect that counsel for the beneficiary were correct in conceding the common law point, id. at 95, [1967] 3 W.L.R. at 955, also recognize the vitality of the Tweddle rule.

The most telling point is that each of the five Law Lords devoted the bulk of his opinion to statutory construction of section 56(l) of the Law of Property Act of 1925 (see text following note 52 infra), and held that the section had not, even inadvertently, destroyed the common law rule; one stanchion of each Lord's argument is that the legislature would not have chosen such an inconspicuous manner to alter the "fundamental rule laid down in Tweddle v. Atkinson." Id. at 105, [1967] 3 W.L.R. at 964. 
tunate circumstance that she was empowered to sue in $A$ 's name as well as her own, this particular beneficiary was accorded a remedy she could not obtain in her own right.

After examining the doctrinal and policy grounds of the rule of Tweddle v. Atkinson, this comment will review two judicial attempts to limit it: the "implied trust" device and, more recently, section 56(1) of the Law Property Act of 1925. The analysis will then focus on the three areas in which adjustments seem to be both desirable for policy reasons and also permissible under current law: (1) $A$ 's intervention in favor of $C$, (2) the creditor beneficiary who has relied on the beneficiary contract, and (3) the effect of $A$ 's death upon the conflicting equities.

\section{The English Rule}

Consideration and privity are the two distinct but interrelated ${ }^{8}$ grounds which have historically been used to justify the Tweddle rule.

8 In Tweddle v. Atkinson, Mr. Justice Crompton declared: "It would be a monstrous proposition to say that a person was a party to the contract for the purpose of suing on it for his own advantage, and not a party to it for the purpose of being sued." 1 B. \& S. at 398, 121 Eng. Rep. at 764. For a modern and more subtle confusion of the privity and consideration rules, see the discussion of the Coulls case, text at note 25 infra. There the persons concerned did all that might reasonably be expected to make the beneficiary a "party," even having her sign the agreement. But since she did not provide consideration, that was not enough.

Since the factual situation which gives rise to litigation on a third party beneficiary contract usually involves an agreement to which $C$ was not a party (often not having been present at all) and under which he gave no consideration, in any given case it may be difficult to determine which factor the court relied on. Tweddle $v$. Atkinson is usually taken to stand for the privity rationale, but it has been cited for the consideration argument as well. In fact, it decided neither. Counsel for the beneficiary Tweddle conceded, perhaps unwisely, that "consideration must move from plaintiff." He merely attempted to show that the family relationship gave rise to an exception, a kind of vicarious consideration, as in the famous case of Dutton v. Poole, reported widely and diversely at 2 Lev. 210, 83 Eng. Rep. 523; T. Jones 102, 84 Eng. Rep. 1168; 3 Keb. 786, 814, 830, 836, 84 Eng. Rep. 1011, 1028, 1038, 1041; 1 Vent. 318, 332, 86 Eng. Rep. 205, 215; 1 Free. 471, 89 Eng. Rep. 352 (K.B. 1677), affd, T. Raym. 302, 83 Eng. Rep. 156 (Ex. 1679). Tweddle lost; such noneconomic, moral consideration had been laid to rest in Eastwood v. Kenyon, 11 Ad. \& E. 438, 113 Eng. Rep. 482 (Q.B. 1840). But see Gale v. Gale, 6 Ch. D. 144, 148 (1877), and cases cited therein.

After a century of being "taught law" (Corbin's phrase), it is perhaps futile and pedantic to question the pedigree of the "rule" of Tweddle v. Atkinson. While it is clear that at an earlier time $C$ had been allowed a right of suit (see notes 32-34 and accompanying text infra), the trend was strongly the other way in the mid-nineteenth century, and returning to the law of centuries ago is hardly feasible or desirable. See the remarks of Mr. Justice Windeyer in Coulls v. Bagot's Ex'r \& Trustee Co., [1967] Austl. Argus L.R. 385, 407-08, and of Lord Upjohn in Beswick, [1968] A.C. 58, 95, [1967] 3 W.L.R. 982, 955 , to this effect. 
In the first place, $C$ has provided none of the consideration for $B$ 's promise. ${ }^{9}$ The concepts of mutuality and bargain-of corresponding rights and obligations springing into being only simultaneously-deny that a "mere volunteer," a "stranger to the consideration," should be permitted to enforce a promise for which he has paid nothing. Second, $C$ is not a party to the agreement; to allow $C$ to sue on a promise not made to him would refute the doctrine of privity, ${ }^{10}$ which views the agreement as a personal matter concerning only those called "parties" to it, namely promisor and promisee. ${ }^{11}$

Behind these formalistic bases for withholding enforcement rights from $C$ are more practical considerations of policy. Since by both the

9 As a creditor beneficiary $C$ might have given the promisee a release, express or implied, in view of the beneficiary contract. But the consideration doctrine strictly demands that the plaintiff must have given consideration to the defendant promisor, or to a person selected by the promisor, in order to maintain an action.

While most beneficiary contracts involve a $C$ who is neither a promisee nor a payor of consideration to $B$, in a few cases $C$ did provide all or part of the price of $B$ 's promise, although the promise itself was made to $A$. In such circumstances, ratification by $C$ may allow him to bring assumpsit as A's principal. Tatam's Case, 1 Rolle Abr. 31, pl. 10 (27 Hen. 8).

10 The early rule was seen as requiring that in assumpsit the promise be made to plaintiff: "[H]e declares a promise made to J.S. and not to himself.-And for this cause principally it was held to be ill, and adjudged for the defendant." Jordan v. Jordan, Cro. Eliz. 369, 78 Eng. Rep. 616 (Q.B. 1595); accord, In re A Communication of Marriage, Het. 12, 124 Eng. Rep. 301 (C.P. 1627); Wallwyn v. Coutts, 3 Mer. 707, 36 Eng. Rep. 272 (Ch. 1815); Price v. Easton, 4 B. \& Ad. 433, 110 Eng. Rep. 518 (K.B. 1833). In the case of covenants made in sealed deeds, since consideration was not necessary, being a party had still greater significance. See Gilby v. Copley, 3 Lev. 139, 83 Eng. Rep. 618 (C.P. 1683); Carnegie v. Waugh, 2 Dowl. \& Ry. 277, I L.J.K.B.(O.S.) 89 (1823).

In one view, it was merely a formality of pleading to allege a promise made to plaintiff in assumpsit pleadings. This was also the proper form when the promise was made to $A$ as C's agent. See Legat's Case, Lat. 206, 82 Eng. Rep. 348; 10 Co. Rep. 108b, 109a, 77 Eng. Rep. 1090, 1093 (K.B. 1627).

11 While "party" in this context is vaguely defined see note 8 supra), ordinarily it includes all promisees and promisors, and only those persons. In the great majority of cases, $C$ is neither a party, nor did he provide consideration, but in some instances $C$ is a joint promisee with $A$ although all the consideration is provided by $A$. In such cases $C$ 's privity with $B$ may overcome the consideration objection, and $C$ may recover in a suit against $B$. In the Coulls case (text at note 25 infra), Mr. Justice Windeyer so argued in his minority opinion:

"The promise is made to [ $A$ and $C$ ] collectively. It must, of course, be supported by consideration, but that does not mean by consideration furnished by them separately. It means a consideration moving from all of them. In such a case the promise of the promisor is not gratuitous; and, as between him and the joint promisees, it matters not how they were able to provide the price of his promise to them. That is the position as I see it. It accords with the very old decision in Rookwood's Case [Cro. Eliz. 164, 78 Eng. Rep. 421; sub nom. Rockwood v. Rockwood, 1 Leon. 192, 74 Eng. Rep. 177 (Q.B. or C.P. 1589)], and with general principle." [1967] Austl. Argus L.R. 385, 405. See also the remarks of Chief Justice Barwick, the other dissenter, id. at 395. Accord, Disborn v. Denabie, 1 Rolle Abr. 30, pl. 5 (1649). Contra, M'Coubray v. Thomson, Ir. R. 2 C.L. 226 (1868). 
privity $^{12}$ and consideration ${ }^{13}$ criteria $A$ is entitled to enforce $B$ 's promise, there is the apprehension that to allow $C$ an independent right of action would expose $B$ to the risk of double recoveries. ${ }^{14}$ For example, after $A$ had recovered damages for breach, $C$ might obtain a decree of specific performance. At an earlier day it seemed necessary to make the policy choice of deciding which person should have the right of action to the exclusion of the other; consideration and privity favored $A .{ }^{15}$ In modern times, however, the flexibility of the English rules regarding joinder greatly reduces this danger: should $A$ bring suit, $B$ may insist that $C$ be joined as plaintiff or defendant, in order to make the outcome binding upon both; if $C$ sues first, $B$ would require joinder of $A .^{16}$

A second policy ground is more important. As a contracting party, $A$ gains important ancillary powers in addition to the fundamental privilege of enforcement. He may rescind or modify the agreement with the concurrence of $B$; he may discharge $B$ from his obligation to convey Blackacre to $C$, or release him for a price; also, $B$ may assign his contract rights to another for consideration. ${ }^{17}$ One specific exercise

12 "[T] $]$ he action well lies for the plaintiff, although the 100l. had been to be paid to a stranger, and not to himself; because the promise is unto him." Taylor v. Foster, Cro. Eliz. 807, 78 Eng. Rep. 1034 (Q.B. 1601) (creditor beneficiary case; $A$ sued $B$ ). Accord, Archdale v. Barnard, 1 Rolle Abr. 30, pl. 3 (K.B. 1607); Ritley v. Dennet, 1 Rolle Abr. 30, pl. 4 (K.B. 1606).

13 E.g., Ritley v. Dennet, 1 Rolle Abr. 30, pl. 4 (K.B. 1606).

14 In Bafeild v. Collard, a suit brought by the administratrix of the promisee, counsel for the promisor defendant moved "that the action ought to have been brought by the daughter $[C]$, for it has been adjudged that it lieth for her upon such a promise, and so the defendant should otherwise be doubly charged; but upon good debate, judgment was given for the Plaintiff, for the consideration moved from the Intestate, and the promise was made to him, yet it was agreed that it might have been brought by the Daughter." Aleyn 1, 82 Eng. Rep. 882 (K.B. 1645).

15 Some early suits gave $C$ the exclusive right to sue, evidently to protect $B$ from double recoveries by $C$ and $A$. See note 33 and accompanying text infra.

16 Rules of the Supreme Court, Order 15, Rules 4(2) and 6(2)(b). The applicability of Rule 4(2) depends on treating $A$ and $C$ as having a "joint" cause of action. There is authority implying they might. Gregory v. Williams, 3 Mer. 582, 36 Eng. Rep. 224 (Ch. .1817); Peel v. Peel, 17 W.R. 586 (Ch. 1869); Gandy v. Gandy, 30 Ch. D. 57 (C.A. 1885) (wife treated as $A$ ); Drimmie v. Davies, [1899] Ir. R. 176 (Ch. 1898); Hohler v. Aston, [1920] 2 Ch. 420 (1919). These cases also illustrate the relative ease with which courts are willing to grant recovery when there is no possibility of prejudice to $B$ by way of multiple claims, since all interested parties are before the court.

If $A$ and $C$ are joint promisees (see note 11 supra), they must join in an action for breach. Anderson v. Martindale, 1 East 497, 102 Eng. Rep. 191 (K.B. 1801) (benefit running only to $C$ ); Jell v. Douglas, 4 B. \& Ald. 374, 106 Eng. Rep. 974 (K.B. 1821); Thomas v. - Style 461, 82 Eng. Rep. 863 (K.B. 1655) ( $C$ may sue separately when the benefits are several).

17 Contract rights also assume some of the aspects of chattel property: they devolve to the personal representative on the death of a party and are subject to the claims of creditors on bankruptcy.

$B$ discharges his contractual obligation only by performance to $C$, until and unless the 
of these ancillary powers is noteworthy: by novation with $B, A$ can so modify the contract as to divert Blackacre to himself. Thus as long as the contract is executory on $B$ 's part, $A$ retains a valuable contingent interest by virtue of his status as the promisee and the provider of consideration, even though $C$ be the only designated beneficiary.

While this valuable cluster of rights is relatively simple to administer when only the rights of $A$ and $B$ are involved, the recognition of a legally enforceable interest in $C$ poses problems of conflicting interests. $C$ 's right of enforcement could only exist at the expense of the ancillary rights of the parties themselves. Where his right to claim the benefit begins, their right to modify, rescind, assign, discharge, or release ends. In resolving this conflict the courts evidently view as controlling the fact that $C$ has paid nothing and that $B$ 's promise was to $A$ rather than $C$. The result is to disregard $C$ 's interests in favor of the parties' unfettered exercise of their ancillary rights. While no court has said that the reason for holding against $C$ is the preservation of $A$ 's ancillary rights, many courts have looked to see whether $A$ 's right to modify or revoke is present and, so finding, have decided against the existence of a possibly conflicting right in $C .{ }^{18}$

$C$ 's position under the Tweddle rule is analogous in several respects to his situation had $A$ merely promised to give him Blackacre. The consideration argument is the same: $C$ has paid nothing which entitles him to enforce any promise or to prevent $A$ from revoking his generosity. ${ }^{19}$ Hence $C$ is denied the right to sue on the executory gift arrangement. But in each instance upon actual receipt of the promised benefit it becomes $C$ 's property; $A$ may not have an action to recover it. ${ }^{20}$ The

agreement has been modified. In re Schebsman, [1944] Ch. 83 (C.A. 1943). Such modification cannot be unilateral; $A$ and $B$ must agree to a diversion of the benefit. Thus if $B$ has a personal interest in seeing that $C$ and not $A$ gets Blackacre, he may refuse to modify. See Davenport v. Bishopp, 2 Y. \& C. Ch. 451, 63 Eng. Rep. 201, (V. Ch. 1843), aff'd, 1 Phil. 698, 41 Eng. Rep. 798 (Ch. 1843).

18 One type of case is illustrated in In re Sinclair's Life Policy, [1938] Ch. 799. A took out an endowment policy for the benefit of $C$, his godson. The court held that $C$ certainly could not have compelled $A$ to continue making payments on the policy; nor could he have prevented $A$ from turning in the policy for its surrender value. Hence, there could be no right of $C$ to the proceeds as against the estate of $A$. In such cases the issue is obscured by the fact that $A$ had not completed performance on his side of the beneficiary contract with $B$. But this should be kept analytically separate from the situation in which $A$ has done all he can to secure the benefit for $C$.

10 This is probably the pertinent inquiry in the analysis of gift promises. "A system of law which does not give the gratuitous promisee a right to enforce the promise is not likely to give this right to a gratuitous beneficiary who is not even a promisee. The doctrines of privity and consideration, though not identical, are intimately connected." $G$. Treitel, The LAW of Contract 446 (2d ed. 1966). However, Treitel makes no distinctionbetween donee and creditor beneficiaries. See text at none 71 infra.

20 In re Schebsman, [1944] Ch. 83 (C.A. 1943), dismissing appeal from [1943] Ch. 366. 
policy seems to be that $A$ 's manifestation-in making the promise to $C$ or in buying B's promise to benefit $C$-is to be treated as conclusive evidence of his intention that the property in the benefit shall pass to $C$ upon receipt.

Although it may therefore be consistent with the gift promise analogy to leave $C$ subject to $A$ 's right to change his mind when $C$ is a donee beneficiary (to whom $A$ by definition has no obligation), ${ }_{0}^{21}$ there may be situations in which detrimental reliance by a creditor beneficiary upon the third party contract may require, from the standpoint of fairness, that $C$ be allowed to enforce the obligation directly.22 Moreover, it is worth noting that the dual criteria of privity and consideration which are used to defeat the claim of the third party beneficiary do not operate in several quite similar donative arrangements. For example, $A$ might contract with $B$ to buy Blackacre, then assign the contract to $C$; or by use of the word "trust" or its equivalent $A$ icould create in $B$ an obligation upon which $C$ might sue as cestui. That $C$ was not a party to the agreement between $A$ and $B$, and had paid nothing for $B$ 's promise, would not bar his actions here..$^{23}$ Moreover, agency is yet another legal construct which would permit $A$ (as $C$ 's agent) to contractually bind $B$ to $C$, although privity be absent between them.

It becomes apparent that it is not the creation of an enforcement interest in $C$ which is proscribed; the beneficiary contract merely does

21 However, some gift promises become binding on the basis of reliance on the part of the promisee, which gives rise to a so-called promissory or equitable estoppel. Crosbie v. M'Doual, 4 Ves. Jr. 610, 13 Ves. Jr. 148, 1 Ves. Jr. Supp. 462, 2 Ves. Jr. Supp. 328, 31 Eng. Rep. 314, 33 Eng. Rep. 251, 34 Eng. Rep. 875, 1117 (Ch. 1806); G. Cheshire \& C. Fifoot, The Law of Contract 82-87 (5th ed. 1960); Simpson, Promises Without Consideration and Third Party Beneficiary Contracts in American and English Law, I5 INT'L \& CoMp. L.Q. 835, 835-48 (1966). It is submitted that donee beneficiaries should be allowed to recover on such grounds under the same criteria applied to gratuitous promisees.

The case of Combe v. Combe, [1951] 2 K.B. 215 (C.A.), has been taken to mean that promissory estoppel cannot be used in England to ground a cause of action affirmatively, but only as a defense (i.e., negatively). This case seems a rather flagrant deviation from the prior law.

22 See text following note 71 infra.

23 "Privity, in the law of contract, is merely the name for a legal relation arising from right and obligation. For example, A, by contract, secures a promise from B. A may transfer his right of enforcement to C. C thereby succeeds to A's right of action, and, in consequence, comes into the relationship with $A$ and $B$ which we call privity of contract. Instead of waiting to do it by assignment, $A$ may, at the outset, exact from $B$ the same promise in favor of C. It is enforceable by $C$, who thereby has come into legal relationship with B." La Mourea v. Rhude, 209 Minn. 53, 57, 295 N.W. 304, 307 (1940).

This passage presents a legal realism view of privity which is not in general acceptance in England. However, it does illustrate the point that assignment accomplishes the same result as a third party beneficiary contract; $C$ 's "privity" with the promisor or lack thereof is the same by either method. 
not comply with the requisite formalities. Since the formalities in the other arrangements mentioned merely serve to assure that $A$ and $B$ have made their intent clear and irrevocable, it is difficult to find any reason why a beneficiary contract should be held to a higher standard, especially since it could be treated equally plausibly as a bilateral contract between $A$ and $B$ combined with a contemporaneous assignment to $C .{ }^{24}$

While the other procedures admittedly are available to wellcounseled people for reaching the desired result, that does not serve to justify a curtailment of $A$ 's freedom of contract, restricting the means by which he may confer rights upon $C$. Moreover, the fact is that for a century since Tweddle $v$. Atkinson people have continued to use the beneficiary contract, perhaps because of its conceptual simplicity, either in ignorance of the rule which denies effect to their expressed intentions or in reliance on $B$ to perform without the need for legal sanctions.

This reliance was thwarted in the recent Australian case of Coulls $v$. Bagot's Executor and Trustee Company, Ltd. ${ }^{25}$ Mrs. Coulls, present during the negotiations, even signed the agreement by which her husband $(A)$ leased quarry land to $B$ in return for $B$ 's promise to pay the royalties to $A$ and $C$ jointly. After $A$ 's death $B$ was faithfully making the payments to Mrs. Coulls as the survivor whereupon the corporate executor requested judicial guidance as to the rights arising from the contract in question. ${ }^{26}$ Since Mrs. Coulls had provided none of the consideration, and since soft language ("I authorize") had been used in the joint payment clause, the High Court of Australia held that the writing was severable into a lease to which she was not a party, and $A$ 's "mere authority" to $B$ as to the manner of payment, which authority expired with the husband. The three man majority thus found it unnecessary to deal with the third party beneficiary issue. ${ }^{27}$

The rule of Tweddle $v$. Atkinson has not been wholly satisfactory

24 For surveys of these and other legislative and judicial exceptions to the strict privity and consideration rules, see e.g., G. Cheshire \& C. Fifoot, The Liw of Contract 368-71, 386-438 (5th ed. 1960); G. Trentel, ThE LAW of Contract 458-75 (2d ed. 1966); Scamell, Privity of Contract, 8 Current Legal Probs. 131, 136-42 (1955).

$25-$ C.L.R. - [1967] Austl. Argus L.R. 385, rev'g In re Estate of Coulls, [1965] So. Austl. State R. 317.

26 This case demonstrates the possible tension between the interests of the third party beneficiary and the legatees, heirs, and creditors of $A$ 's estate. The conflict did not arise in Beswick, where Mrs. Beswick was both the contract beneficiary and $A$ 's administratrix (and possibly his only heir as well). This issue which arises upon the death of $A$ will be dealt with later in the comment. See Part V. infra.

27 For the views of one of the two dissenters, see note 11 supra, and note 69 infra. 
to English legal writers, ${ }^{28}$ legislative draftsmen, ${ }^{29}$ or the courts. ${ }^{30}$ However, the English judiciary evidently feels that reform should be thoroughgoing and well-considered rather than piecemeal-in other words, that change should come from the legislature and not the courts. $^{31}$ They are content in the interim to dispense justice as best they can on a case by case basis, while paying lip service to the letter of the rule. This requires them to rely heavily on the promisee $(A)$ or his personal representative to bring suit as defender of $C$ 's interests.

\section{Judiciar Attempts to Limit the Rule of Tweddle v. Atkinson}

\section{The Early Common Law}

In the sixteenth and seventeenth centuries, before breach of promise had become clearly separated in legal theory from other wrongs, $C$ often successfully maintained his action against $B$ since it was $C$ who had been damnified by the breach: "[T]he party to whom the benefit of the promise accrues may bring his action." 32 In some cases $C$ 's cause of

28 E.g., G. Treitel, The Law of Contract 475-76 (2d ed. 1966); Note, 49 L.Q. Rev. 474 (1933).

29 The Law Revision Committee recommended in 1937 that "where a contract by its express terms purports to confer a benefit directly on a third party it shall be enforceable by the third party in his own name subject to any defenses that would have been valid between the contracting parties." STxth INTERIM REPORT, CMD. No. 5449, at 30 (1937). The current Law Commission is dealing with the question explicitly in its work preparatory to a codification of the law of obligation. Although it reported in 1966 that its work on the matter was "well advanced," FIRST ANNUAL REPORT, 1965-1966, LAw CoM. No. 4, at 8-9, no mention is made of further progress during the last year in its latest report, SECond ANNUAL REPort, 1966-1967, LAW Com. No. 12.

30 It has been termed, inter alia, "a mechanical defect of our law" by Lord Pearce in Beswick v. Beswick, [1968] A.C. 58, 89, [1967] 3 W.L.R. 932, 950. Attempts to avoid the consequences of the rule by judicial contortions such as the trust device (see text at note 36 infra), and section 56(l) of the Law of Property Act, 1925 (see text following note 52 infra), are strong secondary evidence of discontent.

31 Referring to the thirty year hiatus since the recommendations of the Law Revision Committee, Lord Reid brooded: "[D]f one had to contemplate a further long period of Parliamentary procrastination, this House might find it necessary to deal with this matter. But if legislation is probable at any early date I would not deal with it in a case where that is not essential." Beswick v. Beswick, [1968] A.C. at 72, [1967] 3 W.L.R. at 935. The Law Commission has been studying the matter since 1965. FIRST ANNuAL REPORT, 1965-1966, LAw Com. No. 4, at 8.

This comment will be restricted to an examination of those adjustments which seem permissible under the existing general rule, recognizing that sweeping legislative reform would eliminate the necessity of continuing to apply such stopgap judicial modifications.

32 Provender v. Wood, Het. 31, 124 Eng. Rep. 318 (C.P. 1627); accord, Body v. A, Goulsb. 49, 75 Eng. Rep. 986 (C.P.? I587); Manwood v. Burston, 2 Leon. 203, at 205, 93 Eng. Rep. 666 (Ex. 1587); Oldham v. Bateman, 1 Rolle Abr. 31, pl. 8 (1638?); Starkey v. Mill, Style: 296, 82 Eng. Rep. 723, I Rolle Abr. 32, pl. 13 (K.B. 1651); Thomas v. —, 
action was held to exclude $A$ 's, thus preventing the possibility of a double recovery against $B$. This outcome, diametrically opposite to the later Tweddle resolution, is illustrated by a marriage settlement case, Levet $v$. Hawes. ${ }^{33}$ Hawes, a kinsman of the bride, promised Levet, the father of the groom, that upon the marriage he would give the bride a sum of money, in return for which Levet promised to give the bride a certain amount of land, which he did. Upon Hawes' default, Levet brought this assumpsit, pleading the breach and the damages he sustained himself as a result. It was held that the father could not maintain the action since the damage was to the son..$^{34}$

As contract doctrines crystallized, privity and consideration became parallel requirements for the pleading in assumpsit: plaintiff was required to allege a promise made to him and consideration paid by him. In third party beneficiary contract cases, $A$ satisfied these requirements;

Style 461, 82 Eng. Rep. 863 (K.B. 1655); Sprat v. Agar, 2 Sid. 115, 82 Eng. Rep. 1287 (K.B. 1658); Carnegie v. Waugh, 2 Dowl. \& Ry. 277, 1 L.J.K.B.(O.S.) 89 (1823).

A few cases indicated that either $A$ or $C$ might bring an action. Bafeild v. Collard, Aleyn 1, 82 Eng. Rep. 882, Style 6, 82 Eng. Rep. 487 (K.B. 1646); Bell v. Chaplain, Har. 321, 145 Eng. Rep. 478 (Ex. 1674); Hornsey v. Dimocke, 1 Vent. 119, 86 Eng. Rep. 82 (K.B. 1683).

For a glimpse of the confusion in the authorities in this period of transition, see 1 D'Anver's Abridgment 46-48, “(Z) Who Shall Have the Action" (1705) (an annotated translation into English of RoLre's ABRIDGMENT, 1668).

33 Cro. Eliz. 619, 652, 78 Eng. Rep. 860, 891; sub nom. Lever v. Heys, Moore K.B. 550, 72 Eng. Rep. 751 (Q.B. 1598). Hadves v. Levit, Het. 176, 124 Eng. Rep. 433, seems to be an account of the same case, although the parties are reversed, and it purportedly is brought in Common Pleas in 1631, rather than in Queen's Bench in 1598.

The marriage settlement cases generally involve an assumpsit brought by the groom to enforce a promise made by some close relative of the bride (usually her father) to the groom's family before the wedding. According to one view, that the groom almost always recovered does not violate the consideration rule. Until the early nineteenth century the theory was that the marriage itself constituted a sufficient consideration to ground an assumpsit. Such cases would still abrogate the privity rule, however. The plethora of other early cases makes it more likely that at this stage privity and consideration were simply not strictly necessary.

Tweddle $v$. Atkinson also arose from a marriage settlement agreement. In view of the holding, it is not surprising that it was almost the last of the line of cases involving such arrangements.

84 Similarly, in Rippon v. Norton, Norton junior assaulted the Rippons, father and son. Norton senior promised that his son would keep the peace, in return for which Rippon senior withdrew his complaint from the authorities. Norton junior subsequently beat Rippon junior, and Rippon senior brought assumpsit for breach of Norton's promise, pleading the loss of his son's services and the medical expenses as his own damages. Held: the son and not the father must bring the action. Cro. Eliz. 849, 78 Eng. Rep. 1074, (Q.B. 1601). The son then sued and won. Cro. Eliz. 881, 78 Eng. Rep. 1106; Yelv, 1, 80 Eng. Rep. 2 (Q.B. 1601).

There is some indication in the reports that the son's forebearing from complaining of the first attack may have been seen as consideration, and he may even have been a co-promisee, from all that appears. But this very lack of discussion shows that these issues were not very important to the Elizabethan court. 
$C$ did not. But even as the common law courts began to deny $C$ a right of action, culminating in the coup de grace embodied in Tweddle $v$. Atkinson, ${ }^{35}$ the Chancellor began to take a hand.

\section{The Implied Trust Device}

Since $B$ had admittedly assumed a duty to perform to $C$, and the courts of law had found that the legal formalities were lacking, it was perforce an equitable duty ${ }^{36}$ The trust concept of equity provided the mechanism by which such an obligation, liberally construed, created an enforceable right in $C$. While $B$ is specified as trustee in covenants which created express trusts for the benefit of $C$, in this "implied" or "constructive" trust concept, $A$ was usually37 considered to have constituted himself C's trustee, and not of specific property, but of the contractual rights themselves.

Thus, in Gregory v. Williams, ${ }^{38}$ one Parker assigned all of his property to Williams, in return for which Williams agreed to pay Parker's debt to Gregory. Upholding equity jurisdiction over the joint bill filed by Gregory and Parker, the court said:

Now, it may be a doubt whether they could have recovered at law upon this agreement; for the engagement . . . is made to Parker only; and the consideration is furnished by Parker .... Gregory himself furnished no part of that consideration; and he is no party to the contract. Parker acts as his trustee; and Gregory may derive an equitable right through the mediation of Parker's agreement . . . . ${ }^{39}$

35 In one respect at least, Tweddle $v$. Atkinson does stand out as a leading case: the parties could not have made clearer their intention that $C$ was to have the right to enforce the contract. The written agreement itself stated: "It is further agreed by the aforesaid William Guy $[B]$ and the said John Tweddle $[A]$ that the said william Tweddle $[C$, plaintiff in the action] has the full power to sue the said parties in any Court of law or equity for the said sums hereby promised and specified." 1 B. \& S. at 394. The case may be read to stand for the broad proposition that the freedom of contract of $A$ and $B$ is not so extensive as to permit them by contract to give $C$ a right of action on the agreement; and this, after all, is the central issue in the third party beneficiary contract question.

36 "We have to consider, then, what is the effect of such an agreement. Is it not to create an obligation in equity upon $[B]$, in whom the legal interest would be, and was contemplated as being, vested; and in what respect does such an obligation differ from a trust?" Page v. Cox, 10 Hare 163, 168, 68 Eng. Rep. 882, 884 (Ch. 1852).

37 In some cases, however, the courts would simply find that the contract operated as if it created an express trust, i.e., made $B$ the trustee for $C$. See, e.g., Page v. Cox, 10 Hare 163, 68 Eng. Rep. 882 (Ch. 1852).

383 Mer. 582, 36 Eng. Rep. 224 (Ch. 1817).

393 Mer. 582, 589-90, 36 Eng. Rep. 224, 227 (Ch. 1817) (italics in original).

In Tomlinson v. Gill, the prototype of the implied trust decisions, Lord Hardwicke responded similarly: "The plaintiff is proper for relief here for two reasons: 1st, He could not maintain an action at law, for the promise was made to the widow [A]; but 
This trust device had utility in two classes of cases. It permitted $C$ to bring an action in his own name when $A$ would not or could not sue, ${ }^{40}$ and it provided a theory under which it became permissible for $A$ to recover Blackacre or its full value in circumstances wherein he might otherwise encounter difficulty in proving any substantial damage to himself resulting from $B$ 's breach: ${ }^{41}$ the recovery would be in trust for $C_{.22}$ The implied trust device provided a convenient circumvention of the Tweddle rule, allowing to the courts much discretion in reviewing the facts of each case to determine whether to imply a trust.

However, while permitting relief to beneficiaries in appealing circumstances, the device brought into sharp focus the tension between $C$ 's expectations and $A$ 's ancillary contract rights. ${ }^{43}$ If a beneficiary contract was to be read as creating an implied trust from the beginning, $A$ has thereby been $C$ 's trustee from the beginning, and hence is barred from exercising his ancillary powers to the detriment of $C$ 's beneficial interest. Therefore, if $A$ should fall into hard times he would no longer have the right to divert the benefit to his own use. ${ }^{44}$

The trust device, at first applied only in courts of equity, ${ }^{45}$ became

he is proper here, for the promise was for the benefit of the creditors [of whom $C$, the plaintiff, was one], and the widow is a trustee for them." Amb. 330, 331; 27 Eng. Rep. 221, 222 (Ch. 1756). See also Peel v. Peel, 17 W.R. 586, 587 (Ch. 1869).

40 See Gandy v. Gandy, 30 Ch. D. 57 (C.A. 1885); Fletcher v. Fletcher, 4 Hare 67, 67 Eng. Rep. 564 (Ch. 1844).

41 See text preceding note 60 infra.

42 This is the accepted interpretation of Lord Justice Lush's dictum in Lloyd's v. Harper, 16 Ch. D. 290, 321 (C.A. 1880): "It is an established rule that, where a contract is made with $[A]$ for the benefit of $[C],[A]$ can sue on the contract for the benefit of $[C]$ and recover all that $[C]$ could have recovered if the contract had been with $[C]$ himself." But without the trust obligation, $A$ is held to have no basis for recovering the benefit, since $C$ cannot sue him for it, and since $A$ has no obligation to sue for $C$ 's benefit; as the contract stands, $A$ has no right of his own to a benefit promised to $C$. In re Miller's Agreement, [1947] Ch. 615, [1947] 2 All E.R. 78; In re Schebsman, [1944] Ch. 83 (G.A. 1943), dismissing appeal from [1943] Ch. 366.

43 Compare M'Fadden v. Jenkins, 1 Phil. 153, 41 Eng. Rep. 589, aff'g 1 Hare 458, 66 Eng. Rep. 1112 (Ch. 1842), and Paterson v. Murphy, 11 Hare 88, 68 Eng. Rep. 1198 (Ch. 1853), with In re Engelbach's Estate, [1924] $2 \mathrm{Ch}$. 348 (1923), and cases cited therein. See also In re Empress Eng'r Co., 16 Ch. D. 125, 129 (C.A. 1880).

44 One judge, aware of this conflict, proposed the heretical solution that the trust might arise at some future time, rather than at the time of the agreement. Page v. Cox, 10 Hare 163, 169-70, 68 Eng. Rep. 882, 885 (Ch. 1852).

45 Tomlinson v. Gill, Amb. 330, 27 Eng. Rep. 221 (Ch. 1756) ( $C$ was creditor of $A$ 's husband); Gregory v. Williams, 3 Mer. 582, 36 Eng. Rep. 224 (Ch. 1817); Fletcher v. Fletcher, 4 Hare 67, 67 Eng. Rep. 584 (Ch. 1844) (implied trust of a covenant to create an express trust); Lamb v. Vice, 6 M. \& W. 467, 151 Eng. Rep. 495 (Ex. 1840) (penal bond); Page v. Cox, 10 Hare 163, 68 Eng. Rep. 882 (Ch. 1852) (partnership articles providing for widows); Stansfield v. Hellawell, 7 Ex. 373 (1852) (penal bond); Robertson v. Wait, 8 Ex. 299, 155 Eng. Rep. 1360 (1853) (charterparty); Touche v. Metropolitan Ry. Whsg. Co., L.R. 6 Ch. 671, 676-77 (1871) (organizing costs of corporation). 
available in all courts ${ }^{46}$ after the Judicature Acts of 1873 and $1875^{47}$ which merged law and equity into a single administrative system. The line of cases inexplicably ended, ${ }^{48}$ however, at about the time of Professor Corbin's astute exposé in $1930^{49}$ of the widespread usage of this means to defeat the Tweddle doctrine. As a consequence, the privity and consideration requirements fall full force on the unhappy beneficiary in England and in those jurisdictions which feel themselves bound by the English decisions. In Beswick ${ }^{50}$ the trust argument was not even pressed on the appeal, probably because of the unequivocally cold reception accorded it in the courts below ${ }^{51}$ and in other recent cases. ${ }^{52}$

Section 56(1) of the Law of Property Act of 1925

Beswick is important for another reason. It was taken as conceded on the appeal that the widow could not sue in her own right at common law, but it was argued that section 56(1) of the Law of Property Act of $1925^{53}$ had abrogated the common law rule. The section reads:

A person may take an immediate or other interest in land or other property, or the benefit of any condition, right of entry, covenant or agreement over or respecting land or other property, although he may not be named as a party to the conveyance or other instrument.

46 Lloyd's v. Harper, 16 Ch. D. 290 (C.A. 1880) (promise to guarantee insurance contracts); In re Flavell, $25 \mathrm{Ch} . \mathrm{D} .89$ (C.A. 1883) (partnership agreement providing for widows); Les Affréteurs Réunis Société Anonyme v. Walford, [1919] A.C. 801 (charterparty); Royal Exch. Assurance v. Hope, [1928] Ch. 179, [1927] All E.R. 67 (life insurance policy). But see Clitheroe v. Simpson, L.R. 4 Ir. 59 (1879) (marriage settlement); In re D'Angibou, 15 Ch. D. 228 (C.A. 1880) (promise to create an express trust); In re Empress Eng'r Co., 16 Ch. D. 125 (C.A. 1880) (organizing expenses of corporation); Gandy v. Gandy, 30 Ch. D 57 (C.A. 1885) (deed of separation); Cleaver v. Mutual Reserve Fund Life Ass'n, [1892] 1 Q.B. 147 (C.A. 1891) (life insurance policy). These cases, all refusing to apply the trust device, signify a growing tendency toward the end of the nineteenth century to apply strictly the criteria of the Tweddle rule.

4736 \& 37 Vict., c. $66 ; 38$ \& 39 Vict., c. 77.

48 The courts have shown great reticence in discovering the requisite "intention" that a trust be created. In fact, not one English decision since 1930 seems to have implied a trust on what would be recognized as a beneficiary contract. See Green v. Russell, [1959] 2 Q.B. 226, [1959] 3 W.L.R. 17, [1959] 2 All. E.R. 525; In re Schebsman, [1944] Ch. 83 (C.A. 1943), dismissing appeal from [1943] Ch. 366.

49 Corbin, Contracts for the Benefit of Third Persons, 46 L.Q. REv. 12 (1930).

50 [1968] A.C. 58, [1967] 3 W.L.R. 932.

51 See [1966] Ch. 538, 555, 561, 565-66, [1966] 3 All E.R. I (C.A.); [1965] 3 All E.R. 858, 861-62.

52 In re Schebsman, [1944] Ch. 83, [1943] 2 All E.R. 768 (C.A.), dismissing appeal from [1943] Ch. 366; Green v. Russell, [1959] 2 Q.B. 226, [1959] 3 W.L.R. 17, [1959] 2 All E.R. 529 (C.A.).

63 Law of Property Act of 1925, 15 \& 16 Geo. 5, c. 20, § 56(1). 
Section 205(1) of the Act defines "property" to include a "thing in action," but with the saving words "unless the context otherwise requires."

Counsel for the widow-beneficiary placed his reliance on a line of dicta which suggested that section $56(1)$ had eliminated the privity requirement where written instruments were concerned. ${ }^{54}$ In the Court of Appeal, Master of the Rolls Denning, who had long played a liberal role concerning third party beneficiary rights, joined with Lord Justice Danckwerts to form a two-to-one majority in the alternative holding that section 56(1) enabled Mrs. Beswick to recover in her own capacity. The House of Lords put an end to this judicial means of escape from the Tweddle rule by unanimously deciding that the section could not be read so broadly, on the grounds that the statute was a consolidation act. No change in the pre-existing law is to be implied from such acts, since they are enacted without right of debate in Parliament. Thus, the saving clause was employed to narrow the meaning of "property" in the context of section $56(1) .{ }^{55}$

\section{III. $A$ 's Remedies AND the Protection of $C$ 's Interests}

Beswick is representative of the current coupling of the court's desire to see substantial justice done and judicial adherence to the doctrine of $T$ weddle $v$. Atkinson. The courts thus welcome suits brought by $A$ or his personal representative to vindicate $C$ 's interests. Indeed, if $A$ is always willing to sue for $C$ 's benefit and can obtain satisfactory redress, $C$ does not suffer if denied an independent cause of action. Such vicarious suits, however, give rise to new difficulties. First, since $A$ has no direct monetary interest in the outcome of the suit in a donee beneficiary case,${ }^{56}$ his determination to confer Blackacre on $C$ must be quite

54 Denning, L.J., in Drive Yourself Hire Co., Ltd. v. Strutt, [1954] 1 Q.B. 250, 274-75 (1953), and in Smith \& Snipes Hall Farm, Ltd. v. River Douglas Catchment Bd., [1949] 2 K.B. 500, 514-17; Danckwerts, L.J., in Stromdale \& Ball Ltd. v. Burden, [1952] Ch. 223, 235 (1951). This interpretation had been implicitly rejected in White v. Bijou Mansions, Ltd., [1937] Ch. 610, 624-25 (Simonds, J.), aff'd [1938] Ch. 351, 365; and In re Miller's Agreement, [1947] Ch. 615.

55 Beswick v. Beswick, [1968] A.C. 58, 77, 87, 93-94, 104-05, [1967] 3 W.L.R. 932, 939-40, 948-49, 953-54, 963-64.

See Treitel, Law Reform in the Court of Appeal, 29 Modern L. REv. 657, 658.59 (1966), for criticism of the procedural liberality which Lord Denning espoused in his Court of Appeal opinion in Beswick, [1966] Ch. 538, 549-58. The arguments in this court make lively reading.

50 There are exceptions. When $C$ is a creditor beneficiary $A$ obviously will have inducement to enforce the contract against $B$, since if $B$ fails to perform as a reliable conduit $C$ will still have an action against $A$ on the original obligation. Occasionally in a single agreement $B$ promised to benefit both $A$ and $C$; thus $A$ has an interest in enforcing the contract, and this enforcement may result in protecting $C$ 's interest collaterally. Keenan 
strong to bring him into court gratuitously for $C$ 's benefit..57 This is solved in part if $C$ agrees to pay the costs of the suit; $A$ merely allows the action to proceed in his name.

A more substantial problem is the lack of a theoretical basis for full recovery by $A$. While restitution restores him to his original position, $A$ 's desire for recovery commensurate with the loss inflicted on $C$ may require damages in excess of the original consideration. The troublesome issues raised by attempts to apply ordinary contract remedies to beneficiary contract cases have led the courts to favor specific performance in suits by $A$.

\section{Restitution}

$A$ may sue in appropriate cases ${ }^{58}$ for the restitution of his $\$ 5,000$ consideration. He is then free to pay over to $C$ whatever he recovers from $B$, if he continues to desire to benefit $C$. In the donative transaction, this remedy allows $A$ the choice of carrying through with his benevolence or withholding it, a flexibility consonant with the policy concerning gift promises, and thus restitution infringes no legitimate claim of $C$. Similarly, restitution is often appropriate when $C$ is a creditor beneficiary, since $C$ may still sue $A$ on the original obligation, or perhaps on an agency, trust, or assignment theory. ${ }^{59}$

\section{Damages: Nominal or Substantial?}

$A$, the nominal plaintiff, is often met with the contention that he has not himself suffered any legally cognizable injury from $B$ 's breach. Blackacre was to go to $C ; A$ is personally as well off whether $B$ performs or defaults. Thus $A$ cannot sue to obtain Blackacre since it was not promised to him. $G$ has no legal right to Blackacre under the Tweddle rule; moreover, even had $C$ sustained a loss in the eyes of the law, $A$ would have no basis for pleading it in his suit. Further, since under this logic nominal damages seem to be adequate to redress $A$, the

v. Handley, 12 W.R. 930, aff d, 2 De G.J. \& Sm. 283, 46 Eng. Rep. 384 (C.A. Ch. 1864) (B promised to pay $A$ and $C$ separate annuities); Davenport v. Bishopp, 2 Y. \& C. Ch. 451 , 63 Eng. Rep. 201 (1843), aff'd, I Phil. 698, 41 Eng. Rep. 798 (1846) (B promised $A$ the life interest, with remainder to $C)$.

57 Counsel for plaintiff suggested that $A$ would be acting as C's "good fairy." Beswick v. Beswick, [1965] 3 All E.R. 858, 864. It seems clear in the light of $C$ 's peculiar disability to sue that such intervention is not mere meddling, but is in pursuance of C's legitimate interests in enforcing his contract.

68 Restitution is only available when the failure of consideration is complete. Thus, $B$ 's action in paying Mrs. Beswick the first part of the annuity cleverly eliminated this remedy. Treitel, Law Reform in the Court of Appeal, 29 Mod. L. REv. 657, 658 n.16 (1966).

59 See text at note 74 infra. 
equitable remedy of specific performance should not be made available. ${ }^{60}$

When confronted with $B$ 's plea that $A$ should take only nominal damages, the courts have been understandably discomfited and occasionally incensed. ${ }^{61} B$ seems to be saying that since $C$ is barred from suing, and $A$ cannot prove damages to himself, nothing can be done. One answer to the nominal damages plea is that of Mr. Justice Windeyer in Coulls:

I can see no reason why in such cases the damage which $A$ would suffer upon B's breach of his contract to pay C $\$ 500$ would be merely nominal: I think that, in accordance with the ordinary rules for the assessment of damages for breach of contract, they could be substantial. They would not necessarily be $\$ 500$; they could, I think, be less, or more. ${ }^{62}$

This formulation seems correct in the creditor beneficiary situation, since the damages $A$ suffers are on the order of magnitude of the promised benefit- $\$ 500$ here, the value of Blackacre in our original hypothetical-since $A$ remains liable to $C$ on the original obligation. On the other hand, it is difficult to justify a substantial recovery by $A$ in the donee case without taking into account some vague loss of satisfaction on $A$ 's part. While the courts are unwilling to do this, it is submitted that they might be receptive to an argument that $A$ has been damaged in the amount required to make an equivalent gift to $G .{ }^{63}$

60 The courts have been unwilling, however, to follow this argument to its logical conclusion, but rather are inclined to find that nominal damages are somehow "inadequate." See note 69 infra. The nominal damages argument has to date succeeded only in West $v$. Houghton, 4 C.P.D. 197 (1879) (C presumably an incidental beneficiary). It has, however, been raised in several other cases. E.g., Lloyd's v. Harper, 16 Ch. D. 290, 308-10 (C.A. 1880); Lamb v. Vice, 6 M. \& W. 467, 151 Eng. Rep. 495 (Ex. 1840).

The manner in which the implied trust device operates to eliminate this difficulty has been mentioned above. See text at notes $40-42$ supra. If $A$ is willing to sue $B$, he may recover Blackacre or its full value on the theory that he sues as C's trustee, and will pay the recovery over to him. Drimmie v. Davies, [1899] 1 Ir. R. 176, 184, 189, 190 (Ch. 1898). And if $A$ is not willing to sue, $C$ as cestui can sue $B$ directly. Lloyd's v. Harper, $16 \mathrm{Ch}$. D. 290,315 (C.A. 1880).

61 The remarks in the House of Lords decision in Beswick are illustrative: "grossly unjust"-Lord Reid, [1968] A.C. at 73, [1967] 3 W.L.R. at 936; "strange"-Lord Hodson, id. at 78, [1967] 3 W.L.R. at 941; "wholly repugnant to justice and commonsense" -Lord Pearce, id. at 88, [1967] 3 W.L.R. at 949.

62 Coulls v. Bagot's Ex'r \& Trustee Co., [1967] Austl. Argus L.R. 385, 411 (minority opinion).

63 This was the theory which failed in Levet $v$. Hawes in which the father $(A)$ had evidently made money gifts to the newlyweds to help support them, which he would not have had to do had the promisor performed. See text at note 33 supra. But it failed because in the period in question, the courts were disposed to prefer a direct suit by $C I$ 
This would be an equitable and workable resolution to the problem of $A$ 's inability to prove substantial damages to himself. It also overcomes the judicial fear that $A$ would retain the damages after having sued "on the contract" for breach: ${ }^{64}$ here $A$ 's theory depends on the fact that a substitute gift has been or will be made. In a case where $A$ has already made such a substitute gift (Whiteacre) the situation would be very like the "cover" procedure in contracts of sale. ${ }^{65}$ The policy there is that the buyer need not stand still after the seller's default. He may prosecute an alternative method of effecting his original contractual design, and the breaching party must stand ready to reimburse him for the extra outlay occasioned by the breach. If the equivalent gift has not already been made, $B$ or the court sua sponte may insist that the judgment contain the condition that the recovery be in fact turned over to $C$. Under such an order $C$ will obtain a substantive legal right to enforce the judgment:

Any person, not being a party to a cause or matter, who obtains any order, or in whose favor any order is made, shall be entitled to enforce obedience to the order by the same process as if he were a party. ${ }^{66}$

The fact that the suit and order result in the creation of rights in $C$ where none existed before is not as odd as might be supposed. The efforts of $A$ in waging the suit on the equal gift theory are at least as conclusive of his irrevocable intention to benefit $C$ as are the formalities required to create a right in $C$ by means of trust or assignment. As we have seen, the question is not whether $A$ can gratuitously create rights in $C$, it is how (by what formalities, and at what stage in the donative process) $A$ can clearly manifest his irrevocable intention that the rights be vested beyond his power of recall.

In some instances, damages equal to the value of the promised benefit or restitution of the consideration paid may not be wholly adequate to compensate $G$, in the sense of placing him in as good a position as he would have enjoyed had $B$ performed. For instance, if $C$ had made a collateral contract with $D$ to resell Blackacre for $\$ 8,000$ and had in-

64 While restitution implicitly involves a rescission of the agreement, damage and specific performance actions depend on the continued vitality of the contract, thus making it inconsistent for $A$ to attempt to obtain the benefit for himself in contradiction of the terms of the contract. See Davenport v. Bishopp, 2 Y. \& C. Ch. 451, 63 Eng. Rep. 201 (1843), aff'd 1 Phil. 698, 41 Eng. Rep. 798 (Ch. 1846).

65 See Uniform Commercial Code \& 2-712(1).

66 Rules of the Supreme Court, Order 45, rule $9(1)$ ("Execution by or against person not being a party'). In Beswick v. Beswick, [1968] A.C. 58, 81, 91, 100, [1967] 3 W.L.R. 932, $943,952,960$, the court implied that this rule would be applicable in favor of the widow for the enforcement of a decree of specific performance. 
curred legal fees in the process, $A$ may want to compensate $G$ for his lost profit which constitutes $C$ 's "expectation" damages; or he may wish to reimburse $C$ for the outlays made in contemplation of the anticipated benefit, $C$ 's "reliance" damages. ${ }^{67}$

In the past $A$ has not been permitted to plead the value of Blackacre as compensatory damages for $C$ since it is no measure of his own loss. A fortiori, he cannot plead C's reliance or expectation damages in a suit against $B$. But perhaps the equal gift or "cover" device might be extended to allow recovery of the full $\$ 8,000$ as the measure of a consolation gift made to $G .{ }^{68}$

\section{Specific Performance}

Probably the most appropriate remedy for breach of a third party beneficiary contract is a decree of specific performance. It has recently found favor with the courts, ${ }^{69}$ does not involve computation of the value of the consideration given or of the damages suffered, places both $A$ and $C$ in their desired positions by executing the contract in its

67 Generally speaking, reliance damages are out-of-pocket expenses incurred by $C$ in his reasonable reliance on $B$ 's performance; expectation damages are those necessary to place $C$ in as good a position as he would have enjoyed had $B$ performed. See Fuller \& Perdue, The Reliance Interest in Contract Damages (Pt. 1), 46 YALE L.J. 52, 53-54 (1936). The important point is that total damages may exceed the value of the consideration paid or of the promised benefit itself.

68 This would be subject to the ordinary limitations on contract damages, namely that such damages be the normal and consequential results of $B$ 's breach foreseeable at the time of the contract. Hadley v. Baxendale, 9 Ex. 341, 156 Eng. Rep. 145 (1854).

69 It is interesting to note the manner in which specific relief was justified in Beswick, a donee beneficiary case. Nominal damages would appear to have been adequate to compensate $A$ 's estate for the breach, but the court took a broader view of the situation. While $C$ 's interests may not enter into the calculation of adequacy (since under the Tweddle doctrine $C$ had no "rights" to be infringed), $B$ would be unjustly enriched if allowed to take the benefit of his bargain and then default. The court did not explicitly rest on the unjust enrichment aspect, but since "inadequacy" of legal remedies is a prerequisite to the granting of specific equitable relief, it can be inferred that $B$ 's unconscionable gain was the basis for the result. Beswick v. Beswick, [1968] A.C. 58, 73, 89, 97, 102, [1967] 3 W.L.R. 932, 936, 950, 956-57, 961. " $[B]$ has had the full benefit of the contract and the court will be ready to see that he performs his part." Id. at 83, [1967] 3 W.L.R. at $944-45$.

In the dissenting opinions in Coulls, which also favored the remedy of specific performance, little justification was offered for making it available. Mr. Justice Windeyer stated: "It seems to me that contracts to pay money or transfer property to a third person are always, or at all events very often, contracts for breach of which damages would be an inadequate remedy - all the more so if it be right ( $I$ do not think it is) that damages recoverable by the promisee are only nominal. Nominal or substantial, the question seems to be the same, for when specific relief is given in lieu of damages it is because the remedy, damages, cannot satisfy the demands of justice." Coulls v. Bagot's Ex'r \& Trustee Co., [1967] Austl. Argus L.R. 385, 412. But it is hard to see why this rationale, resting on the "demands of justice," will not operate to permit direct suits by beneficiaries. 
original form, and prevents $B$ from being unjustly enriched by his breach. A side benefit is that the decree is enforceable by $C$ in his own right. ${ }^{70}$ Thus in a very roundabout way $A$ 's original desire to provide $C$ with a legally protected interest in the contract benefit is accomplished.

The usual difficulties with specific performance are present. For example, what if the delay occasioned by the default and subsequent lawsuit has rendered $B$ 's performance impossible or has irreparably lessened the value to $C$ of such performance? In such situations, including cases where the delay has caused reliance or expectation damages to $C$ which delayed performance will not cure, $A$ must fall back on his damages or restitutionary remedies.

\section{The Greditor Beneftciary}

The preceding section assumed that $A$ was willing to intervene in $C$ 's behalf. When $A$ is not so inclined, $C$ is normally unable to coerce $B$ to perform. As explained earlier, this result resembles the legal treatment of gift promises and thus seems fair in the donee beneficiary case. There are, however, two situations in which $C$ 's helplessness appears overly harsh and without policy justification: (I) when $C$ is a creditor beneficiary and has relied to his detriment on the contract, and (2) when $A$ has died and $B$ refuses to perform. The remainder of the comment will discuss ways in which existing legal doctrine might be used to achieve better results in these two cases.

When $A$ or his representative refuses to intervene on $C$ 's behalf or when an attempt is made to divert the benefit from $C$, neither the Tweddle rule nor current judicial practice makes a distinction between creditor and donee beneficiaries; ${ }^{71}$ both are denied any claim to the benefit. But when the contract is made by $A$ with a view to rextinguishing an obligation owed by him to $C$, commercial convenience and fairness to $C$ may favor the recognition of a right in $C$ rationalized by whatever device is plausible on the particular facts of each case. This would avoid two separate actions where only one would suffice-the first by $C$ against $A$ on the obligation, the second by $A$ to recover over against $B$ on the beneficiary contract. It is unfortunate that the historical development of English law in this area ${ }^{72}$ has prevented the courts

70 See note 66 and accompanying text supra.

71 One early compiler felt there was a distinction in his time: "There is a Diversity where Goods, \&ec. are delivered to $B$. to be delivered over to $C$. upon a Consideration as to satisfie a Debt, and where it's only as a voluntary Gift." 1 D'ANVER's ABRmGEMENT $64, \mathrm{pl} .5$, n.(h) (1705). See also the rather confused discussion of the point in De La Bar v. Gold, 1 Keb. 44, 63, 121, 83 Eng. Rep. 802, 812, 850 (K.B. 1661).

72 Creditor beneficiaries were nonsuited consistently in courts of law as "strangers to 
from giving favorable treatment to creditor beneficiaries in appropriate circumstances. $C$ has given consideration, albeit to $A$ rather than to $B$; it is implicit, or even explicit, that $B$ 's performance to $C$ is in discharge of $A$ 's obligation. And $B$ 's promise has been duly paid for, although by $A$ rather than $C$. In short, $C$ is due the very benefit which $B$ owes. Especially in arrangements worked out among all three parties, although by distinct contracts, $B$ should not be permitted to object in a later suit by $C$ that his promise had been paid for by $A$ rather than by $C ;^{73}$ this is the internal concern of the promisee and beneficiary. If $A$ has not modified the contract before the time for $B$ 's performance, he has thereby left $B$ obligated to perform. Therefore, allowing $C$ to sue on the breach does not necessarily interfere with $A$ 's ancillary contract rights since the proper time for their exercise is past. There need be no conflict in recognizing enforcement rights in $C$ subject to $A$ 's right to release $B: C$ 's rights are subordinated to $A$ 's, but superior to $B$ 's. Requiring joinder of $A$ as party defendant might be desirable to protect $A$ 's interests fully.

Depending on minor variations in the facts, when $A$ pays or loans $\$ 5,000$ to $B$, who promises to pay $A$ 's antecedent debt of $\$ 3,000$ to $C$, assignment or bailment might be found. ${ }^{74}$ Where $C$ has acquiesced in the substituted method of repayment, such assent might be interpreted as a ratification of $B$ 's agency for the purpose of receiving the monies due $C$. Appropriate conversations between $A$ and $B$, or between $B$ and $C$, might liberally be found sufficient to constitute $B$ as $C$ 's fiduciary. Under such theories $C$ can be afforded a ground of recovery against $B$, removing the need for $A$ 's intervention.

While the preceding arguments are based on convenience, there

the consideration" of the beneficiary contracts. See Bourne v. Mason, 1 Vent. 6, 86 Eng. Rep. 5, 2 Keb. 454, 457, 527, 84 Eng. Rep. 285, 287, 330 (K.B. 1669); Crow v. Rogers, 1 Str. 592, 93 Eng. Rep. 719 (K.B. 1724); Price v. Easton, 4 B. \&. Ad. 433, 110 Eng. Rep. 518 (K.B. 1833). Treatment in courts of equity varied. Compare Gregory v. Williams, 3 Mer. 582, 36 Eng. Rep. 224 (Ch. 1817), and Bell v. Chaplain, Har. 321, 145 Eng. Rep. 478 (Ex. 1663), with Wallwyn v. Coutts, 3 Mer. 707, 36 Eng. Rep. 272 (Ch. 1815).

73 See the remarks of Mr. Justice Windeyer, quoted in note 11 supra.

74 The promise raises a debt to $C$. See Disborne v. Denabie, 1 Rolle Abr. 30, pl. 5 (1649); Oldham v. Bateman, I Rolle Abr. 31, pl. 8 (1638) (semble). C succeeds to $A$ 's claim for money had and received. See Wilson v. Coupland, 5 B. \& Ald. 228, 106 Eng. Rep. 1176 (K.B. 1821). Starkey v. Mill, Style 296, 82 Eng. Rep. 723, 1 Rolle Abr. 32, pl. 13 (K.B. 1631), gives support to a theory that $A$ acts as $C$ 's agent in receiving $B$ 's promise: "[H]ere is a promise in Law made to the Plaintiff, though there be not a promise in fact."

The test of agency in beneficiary contracts is strict, however. In order for $A$ to be considered as having been $C$ 's agent in obtaining the promise of $B, A$ must also have acted as $C$ 's agent in rendering consideration to $B$. Dunlop Pneumatic Tyre Co. v. Selfridge \& Co., [1915] A.C. 847. Unless $C$ has given something up through the agency of $A$, he has no basis for a right of action on $B$ 's promise, since the consideration requirement again interacts with the privity rule. 
may be cases in which there exist more compelling reasons for according $C$ a remedy in his own capacity. While ordinarily, if denied relief against $B$ on the beneficiary contract, $C$ can still sue $A$ on the original obligation, he may occasionally have relied to his detriment upon the beneficiary contract or upon communications regarding it from $A$ and $B$. For example, the statute of limitations may have run on the original debt, or $A$ may have become insolvent. In these situations, $A$ 's ancillary rights should probably yield to $C$ 's need for performance, especially if $A$ is aware of $C$ 's reliance, because $A$ has encouraged the reliance. Since $A$ intended to extinguish the existing debt by means of the beneficiary arrangement, he is likely to have informed $C$ of the indirect mode of satisfaction. Such notice in the United States might give rise to a promissory estoppel, under which $A$ could not later refuse to enforce the contract against $B$. But since promissory estoppel is evidently not available in England for the purpose of grounding a cause of action $^{75}$ (in this case, a suit to compel $A$ to sue $B$ ), $C$ must turn to the argument that his assent to the arrangement constituted a separate contract between $A$ and $C$, with the implied undertaking on $A$ 's part to enforce-and not to modify or release - the beneficiary contract for $C$ 's benefit, in return for which $C$ was to grant $A$ a discharge of the original obligation once $B$ performed. Alternatively, by virtue of $C$ 's ratification of the arrangement, the courts might be disposed to accept an agency, trust, or assignment theory as characterizing the situation, as proposed above. ${ }^{76}$ In any event, $A$ should not be permitted to induce $C$ 's reliance, then refuse to enforce $B$ 's promise. Rather, $A$ 's ancillary rights should give way to $C$ 's equitable claim to the benefit.

\section{V. $A$ 's REPRESENTATIVE}

The second circumstance in which $C$ should probably be allowed to enforce directly the beneficiary agreement occurs when $A$ has died after making the contract. An unhappy generalization can be made from an examination of the cases litigated under the Tweddle rule: while judicial and statutory exceptions have been developed to cover the major commercial situations such as negotiable instruments, grantees assuming mortgages, and certain life insurance policies, the rule falls full force on agreements made between private individuals, amateurs to the art of contract. The common fact setting in an earlier day, the

75 Combe v. Combe, [1951] 2 K.B. 215 (C.A.); see note 22 supra. If this case is not followed, promissory estoppel seems a strong basis for an action where either $A$ or $B$ informs $C$ of the beneficiary contract and he changes his position in reliance on such statements.

76 See text at note 74 supra. 
marriage settlement, has given way to efforts by $A$ to provide for his family's financial security after his death. Thus, at the very time of $B$ 's breach, $A$ has ceased to be in a position to protect the interests of $C$. The rule barring a direct suit by $C$ becomes at once more harsh and more difficult to circumvent.

The personal representative of a party to a contract is said to "stand in the shoes" of his decedent in matters relating to the contract, with the important proviso that he must also act as a fiduciary as to the interests of the estate. Thus $R, A$ 's representative, has the right to enforce contractual terms in favor of the decedent and is liable in return upon contractual obligations incurred by $A$. But a question as yet unanswered by the English courts is whether $R$ is under any duty to $G,{ }^{77}$ who may be a complete stranger to the estate, but who appears as the express beneficiary of $A$ 's contract with $B$, which $R$ is empowered to enforce. If $R$ is under such a duty, assuming that he has succeeded to $A$ 's right to modify the contract by novation with $B,{ }^{78} R$ is drawn into a conflict of interest between $C$ on the one hand and the creditors, heirs, and legatees of $A$ 's estate on the other. ${ }^{79}$

$R$ has three alternative courses of action. He may sue on the contract for the benefit of $G$, thus giving effect to $A$ 's last-known intentions and enforcing the contract terms as they stand. But in so doing he may consume the assets of the estate even though the estate stands to gain nothing by the suit. On the other hand, if $R$ and $B$ so modify the contract as to divert Blackacre to $A$ 's estate, $R$ would be complying with his recognized fiduciary obligations although he rides roughshod over the manifested desire of his decedent. Finally, $R$ may choose to do

77 Just how this duty is to be conceived is a difficult issue. However, implicit in the representative-decedent relationship is a broad fiduciary responsibility on the part of $R$ toward $A$, which might be stretched to permit a right of action by $C$ based on a breach. In other words, if $R$ refused to sue $B$ for the benefit of $C, C$ might be allowed to obtain an order under which $R$ is bound to carry out the expressed wishes of his decedent. Although this seems somewhat unsatisfactory in concept, the heirs or legatees of a decedent must ground their actions against the personal representative on an equally vague duty of the latter. It can scarcely be questioned that they have such a right of action.

78 It would seem that the personal representative has a duty to compromise A's contracts when by so doing he serves the best interests of the estate. See Ahmed Bin Hadjee Mfohamed Salleh Angullia v. Estate \& Trust Agencies (1927), Ltd., [1938] A.C. 624, 632 (P.C.) (Straits Settlements: Singapore).

79 The contest in Coulls v. Bagot's Ex'r. \& Trustee Co., [1967] Austl. Argus L.R. 385, was evidently between $C$ ( $A$ 's second wife) and his next of kin (children by his prior marriage). In re Flavell, 25 Ch. D. 89 (C.A. 1883), and In re Schebsman, [1944] Ch. 83 (C.A. 1943), involve the tension between $C$ and $A$ 's creditors, who want the benefit treated as an asset of the estate. Note that under the contract $A$, hence $R$, had no claim to Blackacre, only the right to enforce, modify, etc. Only when the contract has been modified to divert Blackacre to the estate does such a claim on the res arise. 
nothing, allowing $B$ to perform or breach at will; $R$ would conserve the estate by refraining from a gratuitous suit.

At present the English law is that $R$ may bring suit for the ultimate benefit of $C$, as in Beswick; but the courts have not yet indicated whether $R$ is bound to bring the action, since they seem unwilling until absolutely necessary to open Pandora's box and discuss the possible conflicts with the interests of the estate. ${ }^{80}$ Implicit in the Beswick litigation, as one example, is the notion that $C$ has no right to coerce $R$ to bring suit against $B$, just as he had no right to compel $A$. The result is that the whim of $R$ is left to govern the remedy of $C$, a policy which encourages $C$ to compete with the other parties interested in $A$ 's assets in a race to become administrator or executor, in order to insure that it will be his whim at the helm.

A first improvement on the present state of the law would be to remove the uncertainty from $R$ 's position. The courts should make clear whether $R$ as $A$ 's personal representative must fulfill his fiduciary obligations to the estate by diverting the contract benefit or whether instead $R$ must sue for the benefit of $C$ in his capacity as custodian of $A$ 's contract rights.

Second, it is submitted that the latter course is the better choice; to allow $R$ to deprive the intended beneficiary of the fruits of $A$ 's foresight and generosity-either by novation or inaction-is harsh and tends to defeat the basic policies underlying freedom of contract. The indications in Beswick are that the courts will prefer to see the contract enforced rather than subverted. The controlling policy consideration in the lifetime of $A$, reservation of his ancillary contract rights, such as the right to modify, becomes irrelevant upon his death. $R$ is not qualified to exercise his judgment where choices of personal preference are involved and, therefore, should not be free to bestow or revoke gifts. When contracts such as those in Beswick and Coulls create benefits commencing or increasing on the death of $A$, it is implausible to infer that $A$ contracted with the understanding that the contract would be unenforceable at his death or that it could be modified or released by his representative. The courts have made it clear that Blackacre is not

80 Lord Hodson touched on the subject in Beswick: "It is true that specific performance would not be ordered so as to disregard the fiduciary position which the appellant [suing as $R$ ] occupies as administratrix. Situations might arise in the administration of an estate when there might be conflicting claims between creditors and persons entitled beneficially otherwise, but this is not such a case." [1968] A.C. at 82, [1967] 3 W.L.R. at 944. Lord Upjohn also made a passing reference to the problem, but contented himself with stating that $B$ could not plead such a jus tertii in an action brought by $R$. Id. at 100-01, [1967] 3 W.L.R. at 960 . 
a part of $A$ 's assets for bankruptcy ${ }^{81}$ or estate tax ${ }^{82}$ purposes; $A$ merely has the right of enforcement until he modifies the contract. Only the intangible chose in action devolves to $R$, not the benefit itself. He should therefore treat the contract as he must treat $A$ 's other contracts, and enforce it as written. ${ }^{83}$

If $C$ is given a right to compel $R$ to sue $B$, or if $C$ may sue in the name of $R$, it might again be objected that this creates rights in $C$ when he theoretically gained none from the contract itself. As we have seen, a more meaningful inquiry is whether $A$ 's intention is clear and irrevocable. When death makes revocation by $A$ impossible, to allow $C$ 's interests to ripen no longer infringes $A$ 's ancillary rights.

\section{Conclusion}

While the English courts are not content with the present state of the law regarding third party beneficiary contracts, they are not disposed to initiate a case-by-case judicial reformation of the rule of Tweddle v. Atkinson. Instead, they are pinning their hopes on the Law Commission, which is dealing with the issue in studies preparatory to a codification of the law of obligation. In the meantime, the courts welcome suits brought by the promisee or his personal representative to champion the interests of the beneficiary. The measure of recovery in such lawsuits often poses a difficult issue, thus making specific performance acceptable to the courts. Besides placing the parties in substantially the same position as if there had been no breach, specific performance affords a form of redress which can be directly enforced by the beneficiary.

Consonant with the theory of executory gift promises, the donee beneficiary is left subject to the donor-promisee's right to revoke his donative intention. The creditor beneficiary, however, has a stronger claim on the cooperation of the promisee, from the standpoints of both convenience and equity. And when the promisee dies, there seem to be no valid policy reasons against the vesting of rights in the beneficiary.

81 In re Schebsman, [1944] Ch. 83 (C.A. 1943), dismissing appeal from [1943] Ch. 366. 82 In re Miller's Agreement, [1947] Ch. 615.

83 M'Fadden v. Jenkyns, 1 Phil. 153, 41 Eng. Rep. 589, aff'g 1 Hare 458, 66 Eng. Rep. 1112 (V. Ch. 1842), used the implied trust device to defeat $R$ 's denial of $C$ 's claim. 